\title{
HUBUNGAN MATA KULIAH JATIDIRI BANGSA DENGAN PENINGKATAN WAWASAN KEBANGSAAN DAN SEMANGAT NASIONALISME MAHASISWA \\ (Studi Korelasi di Lingkungan Program Studi PPKn Universitas Buana Perjuangan Karawang)
}

\author{
Fitri Silvia Sofyan \\ Dosen Program Studi Pendidikan Pancasila dan Kewarganegaraan \\ Universitas Buana Perjuangan Karawang \\ e-mail: fitrisofyan@ubpkarawang.ac.id
}

\begin{abstract}
This research is purposed to procure representation about correlations between national identity courses with the students' insight into nationalism and the students' spirit of nationalism in Program Studi PPKn UBP Karawang. This study used quantitative approach with a correlation study method. The data of this study was obtained through questionnaires and tests given to students in Program Studi PPKn UBP Karawang. Researcher revealed that: 1. The implementation of national identity as a general basic course included in personality development course in Program Studi PPKn UBP Karawang had been implemented very well and was able to make a significant contribution, which is in accordance to national identity's goal itself. 2. Students in Program Studi PPKn UBP Karawang were believed to have a good insight into nationalism and a strong nationalism. 3. The application of national identity courses as a general basic course has a strong correlation and a great influence on the improvement of the students' insight into nationalism and the spirit of nationalism in Program Studi PPKn UBP Karawang.
\end{abstract}

Keywords: National identity course, nationality, insight on nationalism, spirit of nationalism, Program Studi PPKn UBP Karawang.

\begin{abstract}
ABSTRAK
Penelitian ini bertujuan untuk memperoleh gambaran mengenai korelasi Mata Kuliah Jatidiri Bangsa dengan peningkatan wawasan kebangsaan dan semangat nasionalisme mahasiswa di Program Studi PPKn UBP Karawang. Penelitian ini menggunakan pendekatan kuantitatif, dengan metode korelasi. Hasil penelitian menunjukkan bahwa 1. Penerapan Mata Kuliah Jatidiri Bangsa sebagai mata kuliah dasar umum Universitas Buana Perjuangan Karawang sudah dilaksanakan dengan sangat baik dan mampu memberikan kontribusi yang besar sebagaimana tujuan dari Mata Kuliah Jatidiri Bangsa itu sendiri. 2. Mahasiswa di lingkungan Program Studi PPKn UBP Karawang memiliki pemahaman wawasan kebangsaan dan semangat nasionalisme yang baik. 3. Penerapan Mata Kuliah Jatidiri Bangsa sebagai mata kuliah dasar umum memiliki hubungan yang kuat dan berpengaruh signifikan terhadap peningkatan wawasan kebangsaan dan semangat nasionalisme mahasiswa di lingkungan Program Studi PPKn UBP Karawang.

Kata kunci : Mata Kuliah Jatidiri Bangsa, Wawasan Kebangsaan, Semangat Nasionalisme, Program Studi PPKn UBP Karawang.
\end{abstract}




\section{PENDAHULUAN}

Bangsa Indonesia adalah bangsa yang majemuk, yaitu bangsa yang terdiri atas berbagai suku bangsa, ras, agama, dan sistem budaya. Identitas bangsa Indonesia tidak bisa terlepas dari keberadaan bangsa Indonesia yang bhinneka. Sebagai bangsa yang majemuk dibutuhkan sikap akomodatif untuk merangkul semua golongan. Satu golongan dengan golongan yang lain harus saling menghormati serta hidup saling berdampingan (koeksistensi) secara damai. Dengan kata lain, harus ada toleransi antar suku, agama, dan budaya. Suatu golongan tidak boleh memaksakan kehendaknya ataupun ideologi (keyakinannya) kepada golongan yang lain.

Negara bangsa (nation-state) Indonesia yang terdiri atas sejumlah besar kelompok-kelompok etnis, budaya, agama tersebut menurut Hefner (Budimansyah dan Suryadi, 2008, hlm.28) "mengilustrasikan Indonesia memiliki warisan dan tantangan pluralisme budaya (cultural pluralism) secara lebih mencolok sehingga dipandang sebagai "lokus klasik" bagi bentukan baru "masyarakat majemuk" (plural society)". Berkaitan dengan hal tersebut Nasikun mengungkapkan "bahwa kemajemukan masyarakat Indonesia paling tidak dapat dilihat dari dua cirinya yang unik, pertama secara horizontal ia ditandai oleh kenyataan adanya kesatuankesatuan sosial berdasarkan perbedaan suku bangsa, agama, adat, serta perbedaan kedaerahan, dan kedua secara vertikal ditandai oleh adanya perbedaan-perbedaan antara lapisan atas dan lapisan bawah yang cukup tajam" (dalam Budimansyah dan Suryadi, 2008 hlm.28).
Gambaran kemajemukan masyarakat Indonesia juga dijelaskan secara terperinci oleh Soebadio (Ruyadi dalam Wilodati, 2010 hlm.157-158) sebagai sebuah potensi dan sekaligus sebagai permasalahan, yaitu sebagai berikut:

(1) Indonesia berupa kepulauan yang luas sekali, lebih dari $5.000 \mathrm{~km}$ dari ujung Barat ke ujung Timur dan hampir $2.000 \mathrm{~km}$ dari ujung Utara ke ujung Selatan. Hal itu kita ketahui semua. Namun, di setiap daerah, pulau atau di dalam perbatasan suatu suku bangsa, hal itu tidak selalu disadari. Memang kebanyakan orang tampak sulit sekali membayangkan betapa luasnya Negara Indonesia ini yang dengan politik Wawasan Nusantara sekarang meliputi wilayah 5 juta km2 secara sah.

(2) Dalam wilayah seluas itu, jumlah pulaunya 13.977 walau hanya sekitar 6.000 yang dihuni. Penduduk dalam pulau-pulau itu beranekaragam, berbahasa lebih dari 300 dialek, malahan di antaranya ada bahasa mandiri, sedangkan adat istiadatnya atau budaya setempatnya beraneka variasi pula. Hal itupun diketahui umum. Namun dalam hal ini juga tidak disadari oleh setiap kelompok atau individu secara perorangan.

(3) Keanekaragaman bahasa dan kebudayaan setempat itu akhirnya memiliki dasar yang sama, dalam arti berasal dari rumpun bahasa 
dan jenis budaya yang sama.

Hal itu ditemukan dalam penelitian sosial budaya yang secara mendalam dimulai oleh sarjana-sarjana asing pada abad ke-19. Masalah dasar bahasa dan budaya yang sama itupun kita ketahui secara umum sejak cukup lama. Tetapi, sekali lagi, hal itu juga tidak selamanya disadari sepenuhnya oleh kita. Seperti juga lambing negara, Bhinneka Tunggal Ika,yang mencerminkan kesadaran akan keanekaragaman dengan dasar yang sama itu dan yang terpampang dimana-mana, akhirnya juga tidak setiap waktu diperdalami maknanya, apalagi dijadikan patokan hidup.

Tantangan yang terjadi dewasa ini adalah pesatnya arus globalisasi yang justru memberikan dampak negatif terhadap kemajemukan tersebut. Pesatnya terknologi dan informasi menimbulkan fenomena kebangsaan yang cenderung berujung pada degradasi semangat nasionalisme dan pemahaman wawasan kebangsaan generasi muda Indonesia. Sebagaimana yang dikemukakan oleh Wildan (2009, hlm.152-153) :

Di era reformasi yang terus bergulir, pemahaman Wawasan Kebangsaan mulai berkurang. Hal ini disebabkan oleh beberapa faktor, antara lain:

1. Adanya keinginan beberapa daerah untuk memisahkan diri dari NKRI dengan berbagai dalih. Kondisi ini mencerminkan kemungkinan adanya disintegrasi;

2. Menonjolnya kepentingan kelompok dan golongan sendiri, sehingga kepentingan yang lebih besar, yaitu kepentingan bangsa dan negara semakin dikesampingkan bahkan cenderung dikorbankan;

3. Menguatnya semangat primordialisme

(mengutamakan putra daerah atau mengklaim kalangan daerahnya sendiri); dan tumbuhnya gejala separatis.

4. Pudarnya asas satu wilayah Nusantara sehingga terjadi pengusiran dan penjarahan milik warga lain yang selama bertahun-tahun bermukim dan berkarya di daerah itu;

5. Penggunaan kekerasan dan pemaksaan atas dasar mayoritas sehingga menimbulkan konflik antaretnis yang minoritas merasa tertindas dan mengadakan perlawanan atau mengungsi ke daerah lain;

6. Mencontoh budaya asing dan menghujat budaya sendiri;

7. Lunturnya budaya penghormatan kepada simbol-simbol negara (Bendera, Lambang Negara, Presiden, dll);

8. Lunturnya semangat kepahlawanan dan perjuangan bangsa (heroisme); 
9. Munculnya sikap apatis terhadap proses pembangunan nasional;

10. Maraknya euforia otonomi daerah; dan

11. Tidak ada rasa hormat dan kebanggaan kepada Bapak Bangsa (the founding father).

Hal ini menjadi dasar utama bahwa perlu adanya suatu solusi yang dapat mempertahankan eksistensi bangsa Indonesia sebagai bangsa yang majemuk sehingga dapat mencapai tujuannya sesuai dengan semboyan "bhineka tunggal ika". Pendidikan menjadi kunci utama bagi kehidupan bangsa Indonesia sebagai salah satu usaha dalam mencerdaskan anak bangsa sesuai dengan amanah Konstitusi. Dalam UU RI No. 20 Tahun 2003 tentang Sistem Pendidikan Nasional Pasal 1 Ayat (1) disebutkan bahwa:

Pendidikan adalah usaha sadar dan terencana untuk mewujudkan suasana belajar dan proses pembelajaran agar peserta didik secara aktif mengembangkan potensi dirinya untuk memiliki kekuatan spiritual keagamaan, pengendalian diri, kepribadian, kecerdasan, akhlak mulia, dan keterampilan yang diperlukan dirinya, masyarakat, bangsa, dan negara.

Salah satu bentuk pendidikan untuk menjawab tantangan ini adalah implementasi mata kuliah jati diri bangsa yang menjadi khas pada Universitas Buana Perjuangan Karawang. Berangkat dari hal tersebut, memunculkan pertanyaan apakah mata kuliah tersebut menjadi salah satu solusi yang dapat menjawab tantangan lunturnya pemahaman wawasan kebangsaan dan semangat nasionalisme Indonesia? oleh karena itu, penelitian ini diharapkan mampu mengetahui korelasi antara mata kuliah Jati Diri Bangsa dengan pemahaman wawasan kebangsaan dan semangat nasionalisme pada generasi muda khususnya mahasiswa.

\section{Rumusan Masalah}

Berdasarkan identifikasi masalah tersebut, maka dapat dirumuskan permasalahannya yaitu adakah korelasi yang signifikan antara Mata Kuliah Jatidiri Bangsa dengan peningkatan wawasan kebangsaan dan semangat nasionalisme mahasiswa di lingkungan Program Studi PPKn FKIP UBP Karawang. Dari rumusan permasalah tersebut, selanjutnya dirinci pertanyaan penelitiannya sebagai berikut :

1. Bagaimana gambaran penerapan mata kuliah Jati Diri Bangsa yang dilaksanakan di Program Studi Pendidikan Pancasila dan Kewarganegaraan Fakultas Keguruan dan Ilmu Pendidikan Universitas Buana Perjuangan Karawang?

2. Bagaimana gambaran pemahaman wawasan kebangsaan dan semangat nasionalisme mahasiswa di Program Studi Pendidikan Pancasila dan Kewarganegaraan Fakultas Keguruan dan Ilmu Pendidikan Universitas Buana Perjuangan Karawang?

3. Adakah korelasi antara mata kuliah Jati Diri Bangsa dengan peningkatan wawasan kebangsaan dan semangat nasionalisme mahasiswa di Program Studi Pendidikan Pancasila dan Kewarganegaraan Fakultas Keguruan dan Ilmu Pendidikan Universitas Buana Perjuangan Karawang? 


\section{Tujuan Penelitian}

Tujuan penelitian berkaitan erat dengan permasalahan penelitian. Tujuan penelitian berisi tentang rumusan hasil yang akan dicapai dalam penelitian yang merupakan jawaban dari pertanyaan penelitian yang dilakukan. Adapun tujuan umum yang ingin dicapai dalam penelitian ini adalah untuk memperoleh gambaran mengenai korelasi mata kuliah Jatidiri Bangsa dengan peningkatan wawasan kebangsaan dan semangat nasionalisme mahasiswa di Prodi PPKn UBP Karawang

Sedangkan tujuan khusus penelitian dapat diuraikan sebagai berikut :

1. Untuk mendeskripsikan gambaran penerapan Mata Kuliah Jatidiri Bangsa yang dilaksanakan di Program Studi PPKn FKIP UBP Karawang.

2. Untuk mendeskripsikan gambaran pemahaman wawasan kebangsaan dan semangat nasionalisme mahasiswa di lingkungan Prodi PPKn UBP Karawang.

3. Untuk mengetahui adakah korelasi Jatidiri Bangsa dengan peningkatan wawasan kebangsaan dan semangat nasionalisme dalam perkuliahan Jatidiri Bangsa di Prodi PPKn UBP Karawang.

\section{METODE PENELITIAN}

Menurut Nazir "metode penelitian merupakan serangkaian langkah secara berurutan sebagai pedoman yang harus dilakukan seorang peneliti dalam melaksanakan penelitian" (2005, hlm.44). Metode penelitian mencakup teknik dan prosedur penelitian. Teknik penelitian berkaitan erat dengan alat dan teknik pengumpulan data. Sedangkan prosedur penelitian merupakan cara atau langkah peneliti dalam melaksanakan penelitian.

Metode yang digunakan dalam penelitian ini adalah metode korelasional dengan menggunakan pendekatan kuantitatif, yakni mendeskripsikan mengenai hubungan korelasi penerapan mata kuliah Jatidri Bangsa dengan peningkatan pemahaman wawasan kebangsaan dan semangat nasionalisme mahasiswa. Dalam penelitian ini peneliti berkeinginan mengungkap fenomenafenomena obyektif dan dikaji secara kuantitatif dan peneliti ingin menjawab pertanyaan penelitian menggunakan pengukuran yang cermat terhadap variabel-variabel penelitian.

Pendekatan penelitian ini digunakan untuk menguji hipotesis yang telah ditetapkan. Sugiono (2008, hlm.14) menjelaskan :

Metode penelitian kuantitatif dapat diartikan sebagai metode penelitian yang berlandaskan pada filsafat positivisme, digunakan untuk meneliti pada populasi atau sampel tertentu, teknik pengambilan sampel pada umumnya dilakukan secara random, pengumpulan data menggunakan instrumen penelitian, analisis data yang bersifat kuantitatif/statistik dengan tujuan untuk menguji hipotesis yang telah ditetapkan.

Nana Sudjana dan Ibrahim (2007, hlm.77) menjelaskan mengenai pengertian dari metode penelitian korelasional, "studi korelasi mempelajari hubungan dua variabel atau lebih, yakni sejauh mana variasi dalam satu variabel berhubungan dengan variasi dalam variabel lain. Hal ini senada dengan Nana Syaodih (2007, hlm.79) "studi hubungan (associational 
study) disebut juga studi korelasional (correlational study), meneliti hubungan antara dua hal, dua variabel atau lebih". Tujuan penelitian ini untuk mendeteksi sejauhmana variasi-variasi pada suatu faktor berkaitan dengan variasi-variasi pada saat atau lebih faktor lain berdasarkan pada koefisien korelasi. Dalam penelitian ini peneliti ingin melihat hubungan dua variabel tanpa coba merubah atau mengadakan perlakuan terhadap variabel-variabel tersebut. Berkaitan dengan hal tersebut Kountur (2009, hlm.54-55) mengemukakan bahwa "penelitian korelasi adalah penelitian yang mencoba melihat hubungan antara beberapa variabel sebagaimana adanya tanpa perlakuan". Melihat apakah mungkin perubahan satu variabel berhubungan dengan perbahan variabel lainnya. Sampel penelitian adalah sebagian atau wakil dari populasi (Arikunto, 2005, hlm.91). Sampel dalam penelitian ini adalah seluruh mahasiswa Program Studi PPKn Tahun Ajaran 2015-2016 di lingkungan Universitas Buana Perjuangan Karawang.

\section{TEMUAN DAN PEMBAHASAN} HASIL PENELITIAN

1. Penerapan Mata Kuliah Jatidiri Bangsa di Universitas Buana Perjuangan Karawang

Berdasarkan hasil perhitungan terhadap prosentase skor masingmasing indikator dapat diketahui bahwa berdasarkan uji statistik, penerapan mata kuliah Jatidiri Bangsa di Program Studi PPKn UBP Karawang tergolong ke dalam sangat baik. Hasil pengukuran statistik ini didukung oleh kondisi di lapangan dimana Program Studi Pendidikan Pancasila dan Kewarganegaraan sebagai kordinator pelaksanaan penerapan mata kuliah Jatidiri
Bangsa sebagai MKU di lingkungan UBP Karawang sudah mampu menerapkan mata kuliah ini dengan baik, sehingga apa yang menjadi tujuan dari mata kuliah inipun dapat tercapai.

Jati diri dalam bahasa Inggris disebut identity adalah suatu kualitas yang menentukan suatu individu atau entitas sedemikian rupa sehingga diakui sebagai suatu pribadi yang membedakan dengan individu atau entitas yang lain. Kualitas yang menggambarkan suatu jatidiri bersifat unik, khas, mencerminkan pribadi individu atau entitas dimaksud. Jatidiri merupakan pencerminan individu atau suatu entitas yang mempribadi dalam diri individu atau entitas, selalu nampak dengan konsisten dalam sikap dan perilaku individu atau entitas yang bersangkutan dalam menghadapi setiap permasalahan.

Terdapat pula pihak yang membedakan antara pengertian identitas diri dan jati diri. Identitas diri lebih menggambarkan penampilan lahiriah dalam bentuk sikap dan perilaku yang membaku dan pribadi seperti ramah, pemarah, introvert, extravert, optimistik, pesimistik, dan sebagainya. Sedangkan jati diri adalah kualitas yang menggambarkan integritas individu atau suatu entitas, sebagai karunia Tuhan, yang mencerminkan harkat dan martabat individu atau entitas dimaksud secara utuh.

Jatidiri mengandung nilai-nilai dasar yang akan memberikan corak terhadap jatidiri bagi pendukungnya. Jatidiri suatu bangsa yang menganut faham individualistik liberalistik akan berbeda dengan jatidiri suatu bangsa yang menganut faham 
kolektivistik, sosialistik atau kegotong royongan.

Jatidiri bangsa akan nampak dalam karakter bangsa yang merupakan perwujudan dari nilainilai luhur bangsa. Bagi bangsa Indonesia nilai-nilai luhur bangsa terdapat dalam dasar negara Negara Kesatuan Republik Indonesia yakni Pancasila, yang merupakan pengejawantahan dari konsep religiositas, humanitas, nasionalitas, sovereignty dan sosialitas. Membangun jatidiri bangsa Indonesia berarti membangun jatidiri setiap manusia Indonesia, yang tiada lain adalah membangun Manusia Pancasila.

Hakekat Mata Kuliah Jatidiri Bangsa adalah untuk membekali dan memantapkan mahasiswa dengan pengetahuan dan kemampuan dasar hubungan warga negara Indonesia yang Pancasilais dengan negara dan sesama warga negara. Visi Mata Kuliah Jatidiri Bangsa adalah merupakan sumber nilai dan pedoman dalam pengembangan dan penyelenggaraan program studi, guna mengantarkan mahasiswa memantapkan kepribadiannya sebagai manusia Indonesia seutuhnya. Misi Mata Kuliah Jatidiri Bangsa adalah untuk membantu mahasiswa memantapkan kepribadiannya agar secara konsisten mampu mewujudkan nilai-nilai dasar Pancasila, rasa kebangsaan dan cinta tanah air dalam menguasai, menerapkan dan mengembangkan ilmu pengetahuan, teknologi dan seni dengan rasa tanggung jawab. Kompetensi Mata Kuliah Jatidiri Bangsa adalah diharapkan mahasiswa menjadi ilmuwan yang memiliki rasa kebangsaan dan cinta tanah air, demokratis yang berkeadaban menjadi warga negara yang memiliki daya saing, berdisiplin dan berpartisipasi aktif dalam membangun kehidupan yang damai berdasarkan sistem nilai Pancasila.

Adapun yang menjadi bahan kajian Jatidiri Bangsa menurut Surat Keputusan tersebut meliputi:

a. Sejarah Nasional Indonesia

b. Prasejarah Indonesia

c. Perkembangan Kerajaan HinduBudha di Nusantara

d. Perkembangan Kerajaan Islam di Nusantara

e. Kedatangan bangsa Eropa ke Nusantara

f. Sejarah Karawang sebagai Kota Pangkal Perjuangan

g. Peristiwa Rengasdengklok

h. Peristiwa Rawagede

Hampir semua orang sepakat karena telah menjadi pengetahuan umum khususnya di kalangan komunitas akademik merujuk pada pendidikan kewarganegaraan (civic/citizenship education) di Indonesia bahkan di negara lain bahwa tujuan pendidikan kewarganegaraan adalah untuk membentuk warga negara yang baik (to be good citizens) begitupun dengan Jatidiri Bangsa. Numan Somantri (dalam Wahab dan Sapriya, 2011, hlm.311) melukiskan warga negara yang baik adalah warga negara yang patriotik, toleran, setia terhadap bangsa dan negara, beragama, demokratis ..., Pancasila sejati. Berhubungan dengan penjelasan warga negara yang baik Azis Wahab mengemukakan sebagai berikut:

Warga negara yang baik adalah warga negara yang memahami dan mampu melaksanakan dengan baik hak-hak dan 
kewajibannya sebagai individu warga negara memiliki kepekaan dan tanggung jawab sosial, mampu memecahkan masalah-masalahnya sendiri dan juga masalah-masalah kemasyarakatan secara cerdas sesuai dengan fungsi dan perannya (socially sensitive, socially responsible, dan socially inteligence), memiliki sikap disiplin pribadi, mampu berpikir kritis kreatif, dan inovatis agar dicapai kualitas pribadi dan perilaku warga negara dan warga masyarakat yang baik (socio civic behavior dan desirable personal qualities) (Wahab dan Sapriya: 2011, hlm.311-312).

Tujuan Mata Kuliah Jatidiri Bangsa dilingkungan Universitas Buana Perjuangan, pada hakikatnya yaitu untuk membekali dan memantapkan mahasiswa dengan pengetahuan dan kemampuan dasar hubungan warga negara Indonesia yang Pancasilais dengan negara dan sesama warganegara. Dengan kemampuan dasar diharapkan mahasiswa mampu menerapkan nilai-nilai tersebut dalam kehidupan sehari-hari; memiliki kepribadian yang mantap, berpikir kritis, bersikap rasional, etis, estetis, dan dinamis, berpandangan luas, bersikap demokratis dan berkeadaban.

2. Pemahaman

Wawasan

Kebangsaan dan Semangat Nasionalisme Mahasiswa PPKn di Universitas Buana Perjuangan Karawang

Sama halnya seperti penerapan mata kuliah Jatidiri Bangsa, kondisi pemahaman wawasan kebangsaan dan semangat nasionalisme mahasiswa di lingkungan Program Studi PPKn UBP Karawang juga dapat dilihat berdasarkan hasil penghitungan terhadap prosentase skor nilai yang didapat pada variabel $\mathrm{Y}_{1}$ dan variabel $\mathrm{Y}_{2}$. Secara statistik, pemahaman wawasan kebangsaan dan semangat nasionalisme mahasiswa di lingkungan Program Studi PPKn UBP Karawang termasuk ke dalam kategori sangat baik, hal ini terlihat dari skor ratarata yang didapatkan responden dalam pengukuran melalui instrumen tes bertingkat. Hasil pengukuran melalui tes bertingkat yang dihitung secara statistik menunjukkan bahwa pemahaman wawasan kebangsaan dan semangat nasionalisme mahasiswa Program Studi PPKn UBP Karawang berada pada kategori sangat baik.

Pemahaman wawasan

kebangsaan dan semangat nasionalisme pada diri individu dipengaruhi oleh banyak hal, namun berdasarkan hasil penelitian penulis memiliki pandangan bahwa dari sekian banyak hal yang mempengaruhi pemahaman wawasan kebangsaan dan semangat nasionalisme, salah satu hal yang memiliki pengaruh sangat besar adalah mata kuliah Jatidiri Bangsa yang sudah ditempuh oleh para mahasiswa di lingkungan Program Studi PPKn UBP Karawang.

Setiap bangsa di dunia memiliki cara pandang terhadap kebangsaan dan tanah airnya masingmasing, dan cara pandang terhadap kebangsaannya itu kemudian disebut sebagai wawasan kebangsaan. Bangsa Indonesia memiliki wawasan kebangsaanya sendiri yang sesuai dengan nilai-nilai Pancasila. Berdasarkan nilai-nilai tersebut 
bangsa Indonesia memiliki cara pandang untuk melangkah ke depan dalam mencapai tujuan nasional.Maliki (2010, hlm.180) berpendapat bahwa "wawasan kebangsaan adalah cara pandang yang dapat memberi pijakan bagi anak bangsa dalam membangun kohesi sosial dan kesepakatan hidup bersama di tengah negeri yang memiliki ribuan pulau, pluralitas etnis, bahasa, budaya, ideologi informal berserta agama".

Wawasan Kebangsaan pada hekekatnya merupakan suatu pandangan atau cara pandang yang mencerminkan sikap dan kepribadian bangsa Indonesia yang memiliki rasa cinta tanah air, menjunjung tinggi kesatuan dan persatuan, memiliki rasa kebersamaan sebagai bangsa untuk membangun Indonesia menuju masa depan yang lebih baik, di tengah persaingan dunia yang globalistik, tanpa harus kehilangan akar budaya dan nilai-nilai dasar Pancasila yang telah kita miliki. Sebagaimana yang tercantum dalam pasal 1 angka 1 Permendagri No.71 Tahun 2012 tentang Pedoman Pendidikan Wawasan Kebangsaan yaitu cara pandang bangsa Indonesia tentang diri dan lingkungannya mengutamakan persatuan dan kesatuan bangsa serta kesatuan wilayah yang dilandasi Pancasila, UUD Negara Republik Indonesia 1945, Bhinneka tunggal ika, dan Negara Kesatuan Republik Indonesia.

Wawasan kebangsaan meliputi mawas ke dalam dan mawas ke luar. Mawas ke dalam artinya memandang kepada diri bangsa Indonesia sendiri yang memiliki wilayah tanah air yang luas, jumlah penduduk yang banyak, keanekaragaman budaya dan lain-lain, harus diletakan dalam satu pandangan yang mendasarkan pada kepentingan bersama sebagai bangsa. Mawas ke luar, yaitu memandang terhadap lingkungan sekitar Negaranegara tetangga dan dunia internasional. Bangsa Indonesia harus memiliki integritas dan kredibilitas yang kuat dalam memainkan perannya di dunia internasional sebagai bangsa yang berdaulat dan bermartabat. Wildan mengemukakan bahwa:

Wawasan Kebangsaan pada hakikatnya adalah kesamaan persepsi dari segenap komponen bangsa Indonesia sebagai dasar bagi terbangunnya rasa dan semangat nasional yang tinggi dalam semua aspek kehidupan nasional. Wawasan Kebangsaan akan menjadi daya dorong untuk berbuat, mempersembahkan, dan mendarmabaktikan karya terbaik bagi bangsa dan negara. Lebih dari itu, hakikat Wawasan Kebangsaan menghendaki dimilikinya sikap untuk segera mengakhiri kesetiaan terhadap kelompok (partai, golongan, suku bangsa) atau perseorangan begitu kesetiaan terhadap bangsa dan negara diperlukan (2009, hlm.154 dalam Tim Sosialiasi Wawasan Kebangsaan Sekretariat Wakil Presiden RI, 2005, hlm.32).

Siswono (1996, hlm.17) mengemukakan bahwa "semangat dan wawasan kebangsaan menjadi penting untuk ditumbuhkembangkan, karena rasa kebangsaan sebagai manifestasi dari rasa cinta 
pada tanah air, pada gilirannya membangkitkan kesadaran kita akan arti mahal dan bernilainya rasa kesatuan dan persatuan bangsa ini". Sebagaimana diungkapkan oleh Lemhanas (2013, hlm.31) :

Wawasan kebangsaan sebagai salah satu aktualisasi nilai-nilai dasar kebangkitan nasional perlu ditularkan kepada seluruh rakyat Indonesia lintas generasi untuk memperkokoh ketahanan bangsa di era globalisasi. Hal ini dikarenakan Wawasan Kebangsaan adalah cara pandang bangsa Indonesia berdasarkan Pancasila dan Undang- Undang Dasar Negara Republik Indonesia Tahun 1945 tentang diri dan lingkungannya dalam mengekspresikan jati diri bangsa di tengah tatanan kehidupan dunia. Wawasan Kebangsaan juga mencerminkan hasrat bangsa Indonesia sebagai bangsa yang merdeka, bersatu, berdaulat, adil dan makmur dalam kebersamaan untuk mengatasi semua hambatan dan tantangan, baik dari luar maupun dari dalam negeri, termasuk rasa kebersamaan dalam menghadapi ancaman separatisme dan radikalisme yang dapat membahayakan persatuan dan kesatuan bangsa.

Maliki (2010, hlm.179) mengungkapkan "pengembangan wawasan kebangsaan adalah sesuatu yang sangat penting dalam upaya membangun kohesi sosial ditengah warga bangsa yang majemuk dan apalagi tengah dibayangi ancaman konflik etnis dan agama". Dengan demikian, wawasan kebangsaan menjadi penting untuk ditanamkan kepada setiap warga Warga Negara Indonesia, khususnya para mahasiswa, dan karena itu perlu disosialisasikan kepada segenap lapisan masyarakat secara terus menerus, bukan hanya sekedar menjadi sebuah gerakan sesaat, tetapi harus diupayakan secara berkesinambungan. Wawasan kebangsaan yang sering didengungkan oleh pemerintah, hendaknya tidak sekedar retorika verbal yang tak pernah diaktualisasikan dalam kenyataan. Namun wawasan kebangsaan harus benar-benar terealisasi dalam kehidupan nyata sehari-hari.

$$
\text { Wawasan kebangsaan }
$$

Indonesia mengamanatkan kepada seluruh bangsa agar menempatkan persatuan, kesatuan, serta kepentingan dan keselamatan bangsa dan negara di atas kepentingan pribadi dan golongan. Diharapkan manusia Indonesia sanggup dan rela berkorban untuk kepentingan bangsa. Berkaitan dengan itu hendaknya dipupuk penghargaan terhadap martabat manusia, cinta kepada tanah air dan bangsa. Wawasan kebangsaan mengembangkan persatuan Indonesia sedemikian rupa sehingga asas Bhinneka tunggal ika dipertahankan. Persatuan tidak boleh mematikan keanekaan dan kemajemukan. Sebaliknya keanekaan dan kemajemukan tidak boleh menjadi pemecah belah namun menjadi kekuatan yang memperkaya persatuan.

Sedangkan semangat nasionalisme yang juga harus dimiliki oleh mahasiswa yaitu "semangat kebersamaan untuk membangun masa depan yang lebih 
sejahtera bagi seluru warga negara Indonesia, dengan tidak membedakan suku, agama, ras, warna kulit, gender atau golongan" (Lemhanas, hlm.107).

3. Korelasi Mata Kuliah Jatidiri Bangsa dengan Peningkatan Wawasan Kebangsaan dan Semangat Nasionalisme Mahasiswa di Lingkungan Prodi PPKn Universitas Buana Perjuangan Karawang

Hasil penelitian menunjukkan bahwa hipotesis yang berbunyi: "Terdapat korelasi yang signifikan antara mata kuliah Jatidiri Bangsa dengan peningkatan wawasan kebangsaan dan semangat nasionalisme mahasiswa di lingkungan Program Studi PPKn UBP Karawang" telah diterima. Hal ini dapat dilihat dari hasil pengolahan data yang menunjukkan adanya tingkat keberartian antaravariabel X (mata kuliah Jatidiri Bangsa) terhadap variabel $\mathrm{Y}_{1}$ (wawasan kebangsaan) dan variabel $\mathrm{Y}_{2}$ (semangat nasionalisme).

Hasil penelitian berdasarkan rumus korelasi yang digunakan Product Moment Coefficient (Pearson's Coefficient Of Correlation) menunjukkan angka $\mathrm{r}_{\mathrm{xy}}$ sebesar 0,694 dan 0,689. Berdasarkan kriteria penafsiran koefesien korelasi yang tertera pada tabel angka tersebut berada pada kategori kuat yakni berada pada rentang 0,60-0,799.

Angka yang dihasilkan melalui rumus korelasi ini juga diolah kembali dengan rumus pengujian determinasi, dan sebagai hasilnya didapatlah nilai koefisien determinasi sebesar $43 \%$ untuk variabel $X$ (mata kuliah Jatidiri Bangsa) dan $\mathrm{Y}_{1}$ (wawasan kebangsaan), 42\% untuk variabel $X$ (mata kuliah Jatidiri Bangsa) dan $\mathrm{Y}_{2}$ (semangat nasionalisme). Berdasarkan angka determinasi tersebut dapat disimpulkan bahwa mata kuliah Jatidiri Bangsa sebagai MKU tingkat universitas memberikan konstribusi yang signifikan terhadap pemahaman wawasan kebangsaan dan semangat nasionalisme mahasiswa di lingkungan Program Studi PPKn UBP Karawang.

Besarnya angka koefisien determinasi pada penelitian ini tidak terlalu mengejutkan, karena sebagaimana kita pahami bahwa memang penerapan mata kuliah Jatidiri Bangsa di Program Studi PPKn UBP Karawang berada dalam kategori sangat baik/sangat tinggi. Hal ini tidak begitu saja tertulis, melainkan telah menjadi pengamatan penulis jauh sebelum penelitian ini, namun dalam perspektif penulis sebagai peneliti yang diajarkan untuk menganalisa sesuatu secara ilmiah dan sistematis, maka penelitian ini dianggap perlu.

Hasil penelitian ini telah membuktikan bahwa penerapan mata kuliah Jatidiri Bangsa sebagai MKU berperan penting bagi peningkatan wawasan kebangsaan dan semangat nasionalisme mahasiswa Program Studi PPKn UBP Karawang. Hal ini sangat masuk akal karena sebagaimana telah disampaikan pada bab sebelumnya bahwa materi yang berkaitan dengan wawasan kebangsaan dan semangat nasionalisme sudah terintegrasi dalam perkuliahan Mata Kuliah Jatidiri Bangsa, sehingga disadari atau tidak, keterlibatan penerapan perkuliahan tersebut akan mempengaruhi terhadap peningkatan wawasan kebangsaan dan semangat 
nasionalisme mahasiswa di lingkungan Program Studi PPKn UBP Karawang.

Berdasarkan temuan penelitian secara keseluruhan maka rumusan masalah pada penelitian ini telah terjawab. Hal tersebut menunjukkan pula bahwa Mata Kuliah Jatidiri Bangsa di Program Studi PPKn UBP Karawang memiliki peranan yang penting guna meningkatkan pemahamana akan wawasan kebangsaan dan semangat nasionalisme mahasiswa di lingkungan Universitas Buana Perjuangan Karawang.

Mata kuliah Jatidiri Bangsa memiliki peran penting dalam suatu kehidupan berbangsa dan bernegara. Mata kuliah Jatidiri Bangsa juga berkontiribusi penting dalam menunjang tujuan bernegara. Sebagai kelompok matakuliah pengembangan kepribadian yang memberi orientasi bagi mahasiswa dalam memantapkan wawasan dan kesadaran kebangsaan, cinta tanah air, demokrasi, penghargaan atas keragamaan dan partisipasinya membangun bangsa berdasar Pancasila. Sebagai kelompok mata kuliah pengembangan kepribadian yang menyelenggarakan pendidikan kebangsaan, demokrasi , HAM, multikulural dan kewarganegaraan kepada mahasiswa guna mendukung terwujudnya warga negara yang cerdas, terampil dan berkarakter sehingga dapat diandalkan guna membangun bangsa dan negara berdasar Pancasila dan UUD 1945 sesuai dengan bidang keilmuan dan profesinya.

Dalam era globalisasi sekarang ini, mata kuliah Jatidiri Bangsa merupakan salah satu jawaban untuk mencetak kader-kader bangsa yang memiliki pemahaman akan wawasan kebangsaan dan juga semangat nasionalisme dalam rangka untuk memecahkan persoalan kebangsaan yang semakin kompleks. Mata Kuliah Jatidiri Bangsa merupakan salah satu bidang kajian dalam konteks pendidikan yang diterapkan dilingkungan universitas memiliki peran strategis untuk meningkatkan kembali wawasan kebangsaan dan semangat nasionalisme mahasiswa.

Mata kuliah Jatidiri Bangsa di lingkuangan Universitas Buana Perjuangan Karawang merupakan sumber nilai dan pedoman dalam pengembangan dan penyelengaraan program studi, guna mengantarkan mahasiswa memantapkan kepribadiannya sebagai manusia seutuhnya. Hal ini berdasarkan pada suatu realitas yang dihadapi, bahwa mahasiswa adalah sebagai generasi bangsa yang harus memiliki visi intelektual, religius, berkeadaban, berkemanusiaan dan cinta tanah air dan bangsanya. Dengan adanya Mata Kuliah Jatidiri Bangsa diharapkan dapat membantu mahasiswa memantapkan kepribadiannya, agar secara konsisten mampu mewujudkan nilai-nilai dasar Pancasila, rasa kebangsaan dan cinta tanah air dalam menguasai, menerapkan dan mengembangkan ilmu pengetahuan, teknologi dan seni dengan rasa tanggung jawab dan bermoral. Berkaitan dengan itu mahasiswa diharapkan akan mampu untuk menjaga dan meneruskan citacita pembangunan bangsa dengan sungguh-sungguh mencintai bangsanya sendiri, dengan tidak membeda-bedakan setiap suku, ras, maupun agama yang mendiami di bumi pertiwi Indonesia. Dengan wawasan kebangsaan dan juga 
semangat nasionalisme maka hal ini diharapkan agar kita dapat menjaga keutuhan Negara Kesatuan Negara Indonesia agar tidak terpecah belah.

\section{SIMPULAN}

Merujuk kepada hipotesis penelitian yang diajukan, maka secara umum kesimpulan penelitian ini adalah proses perkuliahan Jatidiri Bangsa yang tergabung dalam mata kuliah umum di lingkungan Universitas Buana Perjuangan Karawang, khususnya Prodi PPKn memiliki keeratan hubungan yang kuat dan memberikan kontribusi yang besar dalam peningkatan wawasan kebangsaan serta dampaknya terhadap semangat nasionalisme bagi mahasiswanya. Secara khusus kesimpulan penelitian ini sebagai berikut:

1. Proses perkuliahan Jatidiri Bangsa sebagai Mata Kuliah Dasar Umum yang diterapkan di Prodi PPKn Universitas Buana Perjuangan Karawang sudah dilaksanakan dengan baik dan mampu memberikan kontribusi yang besar sebagaimana tujuan dari mata kuliah Jatidiri Bangsa itu sendiri.

2. Mahasiswa di lingkungan Program Studi Pendidikan Pancasila dan Kewarganegaraan memiliki pemahaman wawasan kebangsaan dan semangat nasionalisme yang sangat baik.

3. Proses pekuliahan Jatidiri Bangsa sebagai mata kuliah dasar umum memiliki hubungan yang kuat dan berpengaruh signifikan terhadap peningkatan wawasan kebangsaan serta dampaknya terhadap semangat nasionalisme mahasiswa di lingkungan Universitas Buana Perjuangan Karawang.
Berdasaran kesimpulan hasil uji hipotesis penelitian di atas, maka dirumuskanlah beberapa kesimpulan hasil penelitian sebagai berikut: Pertama, kondisi proses perkuliahan Jatidiri Bangsa sebagai mata kuliah dasar umum, kondisi pemahaman wawasan kebangsaan dan semangat mahasiswa di lingkungan Prodi PPKn Universitas Buana Perjuangan Karawang termasuk pada kategori sangat baik dengan klasifikasi yang sudah ditentukan sebelumnya. Kedua, keeratan masing-masing variabel mata kuliah Jatidiri Bangsa terhadap peningkatan wawasan kebangsaan dan semangat nasionalisme mahasiswa di lingkungan Prodi PPKn Universitas Buana Perjuangan Karawang bervariasi.

\section{DAFTAR REFERENSI Sumber Buku,}

Arikunto, S. (2005). Prosedur Penelitian. Jakarta: Rineka Cipta.

Budimansyah dan Suryadi. (2008). PKn dan Masyarakat Multikultural. UPI : Sekolah Pascasarjana Program Studi Pendidikan Kewarganegaraan.

Kountur, Ronny. (2009). Metode Penelitian untuk Penulisan Skripsi dan Tesis. Jakarta : PPM.

Maliki, Zainuddin. (2010). Sosiologi Politik: Makna Kekuasaan dan Transformasi Politik. Yogyakarta: Gajah Mada University Press 
Nazir, Moh. (2005). Metode Penelitian. Bogor: Ghalia Indonesia

Sudjana, Nana dan Ibrahim. (2007). Penelitian dan Penilaian Pendidikan. Bandung : Sinar Baru Algesindo.

Syaodih, Nana. (2007). Metode Penelitian Pendidikan. Bandung : PT. Rosda Karya Remaja..

Wahab, Abdul Aziz dan Sapriya. (2011). Teori dan Landasan Pendidikan Kewarganegaraan. Bandung: Alfabeta.

Winataputra, U.S., \& Budimansyah, D. (eds). (2012). Pendidikan Kewarganegaraan dalam Perspektif Internasional: Konteks, Teori, dan Profil Pembelajaran. Bandung: Widya Aksara Press.

\section{Sumber Jurnal dan Artikel}

Iriany, Ieke Sartika (2014). Pendidikan Karakter sebagai Upaya Revitalisasi Jati Diri Bangsa. Jurnal Pendidikan Universitas Garut, Vol 08; No 01, hal : 5485

Lemhanas. (2013). Aktualisasi Semangat Kebangkitan Nasional Guna Memantapkan Wawasan Kebangsaan Lintas Generasi dalam Rangka Ketahanan Nasional. Jurnal Kajian Lemhannas RI, Edisi 15, hal : 30-40.
Lemhanas. (2012). Memperkokoh NilaiNilai Pancasila di Seluruh Komponen Bangsa untuk Memantapkan Semangat Kebanngsaan dan Jiwa Nasionalisme Ke-Indonesiaan dalam Rangka Menangkal Ideologi Radikalisme Global. Jurnal Kajian Lemhannas RI, Edisi 14, hal :97-121.

Winataputra, Udin S. (2014). Pendidikan Kewarganegaraan dalam Perspektif Internasional. Jurnal Acta Civicus, Vol 1 Edisi Oktober (1).

Wildan, Dadan. (2009). Pendidikan Wawasan Kebangsaan di Era Reformasi Gelombang Kedua Untuk Mewujudkan Visi Indonesia 2015. Jurnal Sekretariat Negara Republik Indonesia, (14), hal :150-164.

Wilodati. (2010) . Unity and National Harmony Dalam Bingkai Bhinneka Tunggal Ika. Jurnal Sekretariat Negara Republik Indonesia, (16), hal : 150-173.

\section{Peraturan Perundang-Undangan}

Undang-Undang Dasar Negara Republik Indonesia Tahun 1945

$\begin{array}{clc}\text { Undang-Undang } & \text { No.20 } & \text { Tahun } 2003 \\ \text { tentang } & \text { Sistem } & \text { Pendidikan } \\ \text { Nasional. } & & \end{array}$

